\title{
第1章 溶接法および機器
}

\section{$1-2$ \\ ミグ/マグ溶接*}

平田好 則 $^{* *}$

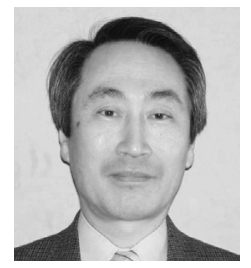

Gas shielded Metal Arc Welding*

by HIRATA Yoshinori*

キーワード ガスメタルアーク溶接, 溶滴移行形態, 表面張力, 絲垂液滴, 橋絡液柱, 電磁力, パルス電流, シミュレーション

\section{1.はじめに}

本誌「溶接接合教室」は，溶接技術者や研究者を主た る読者対象としており，既存の教科書の記述を補う参考 書として機能するように企画されている。そこで，本稿 では溶接学会編【溶接・接合技術特論】ならびに【溶 接・接合技術概論】2) 引用文献として，「第 1 章 溶接法お よび溶接機器」のなかの一項目として記述されている 「ミグ溶接およびマグ溶接」のなかから，溶滴移行現象を 中心に解説することにする.

さて，アーク溶接法はDavyによるアーク放電の発見 （1801）から約 100 年かけて，炭素アーク溶接法やメタル アーク溶接法などの原理が生み出され, 試験的に製品へ の適用がなされたものの，実用的には被覆アーク溶接棒 の発明（1907）が，その後の製造各分野へのアーク溶接 プロセスの適用を加速したと言える。アーク溶接プロセ スは，とりわけ造船や鋼橋の組立て技術として活用され， 大きく発展してきたが，欧米・日本においては，第 2 次 世界大戦前後の艦艇製作技術に関連して，そのポテンシ ヤルが広く認識されたものと思われる。そして，1950年 代後半からはじまった高度成長時代に, 労働集約型の造 船業や重工業分野のキーテクノロジーとなり，材料や部 品をつなぐ方法として不可欠な技術となった.

その後, 国内外での激しい競争に勝ち残るため, 生産 性向上と品質安定化を目指して，アーク溶接法は進化を 続けてきた。とりわけ，マグ溶接や炭酸ガス溶接などの ガスメタルアーク（GMA）溶接は, 被覆アーク溶接のよ うな棒継ぎをする必要がなく，電極ワイヤによる連続溶

*原稿受付 平成20年5月11日

**正 員 大阪大学大学院 工学研究科 マテリアル生産科学専攻 Mnmber, Osaka University, Graduate School of Engineering
接が可能であること, また, 細径ワイヤを用いるため, ワイヤ溶融速度（溶着速度）が大きくなり, 高能率溶接 法として製造各分野で広く利用されるようになった。さ らに，1980年代にはいり，溶接ロボットが市販され，普 及するとともに，ガスメタルアーク溶接は，ロボット化 や自動化に適した溶接方法として, 施工現場での適用割 合が大幅に増加し, 現在に至っている.

\section{2. ガスメタルアーク溶接技術の現状}

ガスメタルアーク（GMA）溶接法は，図 1 に示すよう に，溶接ワイヤが電極となる．多くの場合，直流棒プラ ス極性（DCEP）で使用されている．電極である溶接ワイ ヤはアーク熱により溶融し, 溶滴を形成して母材へ移行

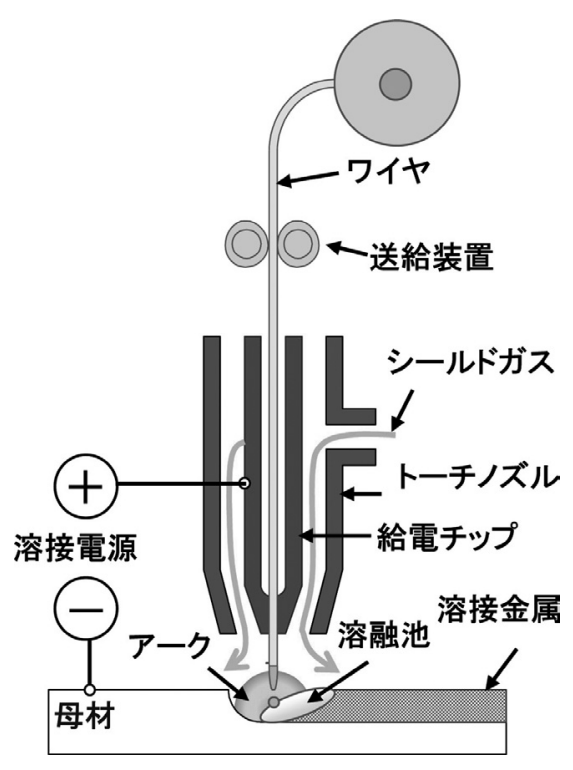

図 1 ガスメタルアーク溶接法の原理 


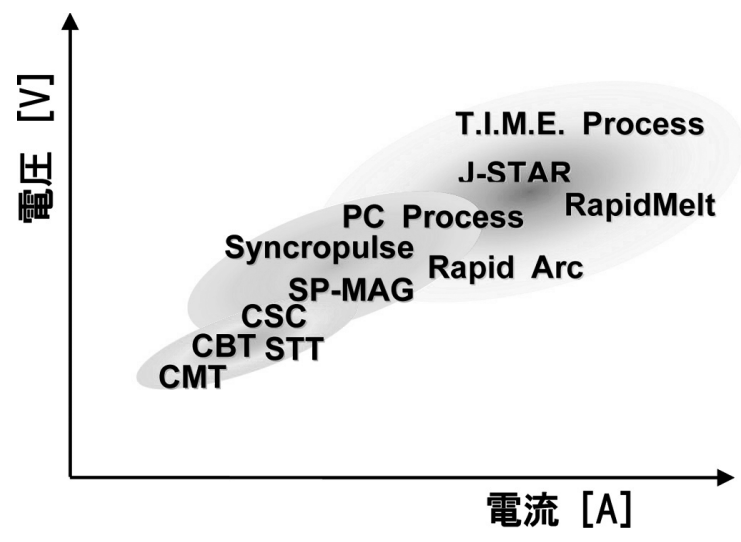

図２ささまざまなガスメタルアーク溶接法

するので，ワイヤ端から溶滴が離脱するたびに，アーク 長やアーク発生位置が断続的に変化する。従って, 移行 する溶滴の大きさや形，移行頻度はアークの安定性を支 配することから，ガスメタルアークはティグアークに比 べると時間的・空間的に変動する熱源であると言え，移 行現象の安定性は溶接品質と作業性に直結している。す なわち，電極棒端から移行する溶滴サイズが，大きすぎ たり，ふぞろいになったりすると，溶滴移行にともなう アーク長の変動が大きくなり，アークが不安定になる. また，溶滴の移行がスムーズでないと，溶接棒端や溶融 池からの溶融金属の飛散するスパッ夕現象が激しくなる. このため, 世界各地の溶接機メーカをはじめ, 溶材メー カやガスメーカ, 大学・研究所などが, 電源性能ならび にシールドガス組成，ワイヤ化学成分に注目して，生産 性や品質の改善に寄与する溶接法を開発してきた。これ らは，メーカによってそれぞれ独自の名称をつけられ， その特長をアピールしながら, 市場に投入され, 製品や 継手の種類，施工現場のニーズに応じて，その役割を果 たしてきている3(-9). 図 2 はこれまでに開発されたガスメ タルアーク溶接法のいくつかを電流・電圧条件上にプロッ トしたものである。これらプロセスのキャッチフレーズ は, 溶滴移行・アークの安定化, スパッタフリー, 溶着 量の増大，溶込み深さの増大，アークの指向性向上，溶 込み形状・余盛形状の改善など多岐にわたっており，実 際の施工現場に導入したときに，具体的にどのような効 果が発揮されたのか明らかでない。これには，溶接機に 付随する溶接プロセスを売るための商品戦略もあるが, 本質的には溶滴移行などの溶接現象が定性的な理解にと どまっていることが最も大きな要因と考えている.

\section{3. 溶滴移行形態}

溶極式アークの発生状態や溶滴移行の状況はサブマー ジアーク溶接を除いて，直接目で見ることができる．IIW (国際溶接学会) では，移行形態を図 3 のように溶滴の形 や大きさ，移行状況など外観的な特徵をもとに分類し， 統一された用語でもって，同じ現象に対して世界中の技 術者・研究者が共通の認識を持てるように実務や研究の 便宜を図っている ${ }^{10)}$. 溶滴移行形態には大別すると，(1)自 由移行：溶滴がアーク柱内を移行する（アーク長が長く,
アーク電圧が高い) と, (2)橋絡移行：溶融ワイヤ端部が 母材溶融池と接触・橋絡し, 移行する（アーク長が短く, アーク電圧が低い）がある.さらに，自由移行において は, 溶滴の大きさがワイヤ径よりも大きい場合をグロビ ユラー移行, ワイヤ径と同じかそれよりも小さい場合を スプレー移行と呼んでいる. そして, グロビュラー移行 のなかで, 溶滴の形状が球状に近いものをドロップ移行, 炭酸ガス溶接で見られるような溶滴形状が変動している ような移行形態を反発移行と呼んでいる。一方，ガスメ タルアーク溶接においては, 溶滴と溶融池が接触する場 合，同時に電気回路の短絡が生じているので，短絡移行 とも呼ばれている。これらの移行形態は溶接法や溶接条 件 (電流, 電圧), 極性, シールドガス, ワイヤの材質 · 種類 (ソリッド, コアード), ワイヤ径, 母材など多くの 操作因子によって変化する。（注：パルスアーク溶接など の電流波形・ワイヤ送給を制御するミグ/マグ溶接法が現 在, 世界各地で普及しているので, IIW では溶滴移行形 態の分類を見直す方向で検討が進められている.)

ソリッドワイヤのガスメタルアーク溶接では, シール ドガスを定めると, 図 4 のように溶接電流とアーク電圧 (アーク長) によって移行形態が変化する.ミグ溶接やマ グ溶接などアルゴンガスの混合比が高いシールドガスを 適用すると, 或る臨界電流值を超えると, グロビュラー 移行からスプレー移行に遷移する. 図 5 は一定電流のミ グ溶接における溶滴の移行回数と電流との関係を示す ${ }^{11)}$. $1.2 \mathrm{~mm}$ 径の軟鋼ワイヤでは約 $230 \mathrm{~A}$ (スプレー化の臨界 電流）を超えると移行回数が急激に増加する，溶接電流 とともに電極ワイヤの溶融量も多くなるが, それにも増 してワイヤから移行する溶滴の数が増加するので, 溶滴 1 個当りの体積が小さくなるスプレー移行の状態になる ことを示している. 図から例えば， $350 \mathrm{~A}$ の場合，1秒間 に約 500 個の溶滴が離脱・移行するわけであるから, 原 理的には溶滴 1 個当り $2 \mathrm{~ms}$ の期間, $350 \mathrm{~A}$ の電流を与え てやればよいことになる。したがって，図 $6{ }^{12)}$ に示すよ うにピーク電流に応じたパルス幅のパルス電流を適用す れば，平均電流值を低くしても 1 パルス当りに 1 回溶滴 が離脱・移行する 1 パルス 1 溶滴移行が実現できること になる. 1 パルス 1 溶滴移行では, 溶滴サイズがそろっ た規則正しい移行が行われ，極めて安定なアークが得ら れ，スパッ夕の発生も少ない.

マグガスは日本国内では $\mathrm{Ar} 80 \%-\mathrm{CO}_{2} 20 \%$ 組成の混合ガ スが一般的であるが, 海外も含めて用途に応じて, 種々 の組成比が使用されている。アルゴンガスと炭酸ガスの 混合比によって, 溶滴サイズとスパッ夕の発生量がどの ように変化するかを電流值 $300 \mathrm{~A}$ について実験的に調べ たものを図 $7^{13)}$ に示す. 図から, 炭酸ガスの混合比が増 加するとともに, 溶滴サイズが大きくなり, これに伴っ て，スパッ夕の発生量も増加することが分かる．また， 炭酸ガスの混合比を $25 \%$ 程度よりも少なくすると, 溶滴 サイズがワイヤ径よりも小さくなり，スプレー化するこ とが分かる。しかしながら，移行形態の遷移が生じる電 流・電圧の值が，何によって決定されるのか，また， シ ールドガスや母材・ワイヤ中の合金元素が移行に対して, どのような影響を及ぼすのかについては十分に明らかで 
IIW分類による溶滴移行形態(IIW Doc.XII-636-76,1976)

\section{移行形態名}

1. 自由移行

1.1 グロビュラー移行

1.1.1 ドロップ移行

1.1 .2 反発移行

1.2 スプレー移行

1.2.1 プロジェクト移行

1.2.2 ストリーミング移行

1.2.3 ローテーティング移行

1.3 爆発移行

2. 橋絡移行

2.1 短絡移行

2.2 連続橋絡移行

3. スラグ-プロテクト移行

3.1 壁面移行

3.2 その他のモード
溶接法(例)

低電流GMA

$\mathrm{CO}_{2}$ アーク

中間電流域GMA

中電流GMA

大電流GMA

SMA(被覆棒)

ショートアーク

フイラーワイヤ添加時の溶接

サブマージアーク

SMA,コアードワイヤ,エレクトロスラグ<smiles>C1=CC2CCCC2C1</smiles>

ドロップ移行

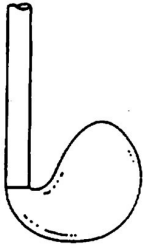

反発移行

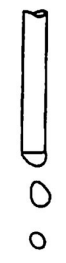

プロジェクト移行

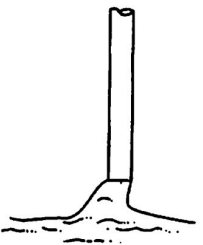

短絡移行

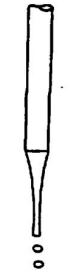

ストリーミング移行

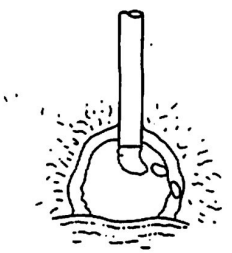

壁面移行

図 3 溶滴移行形態の分類

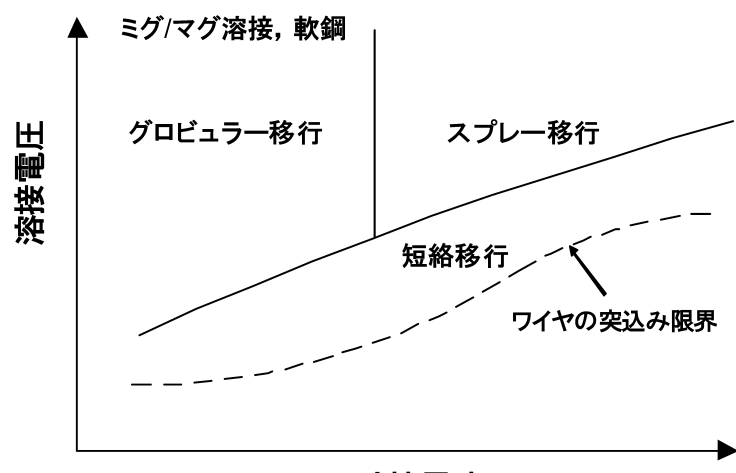

溶接電流

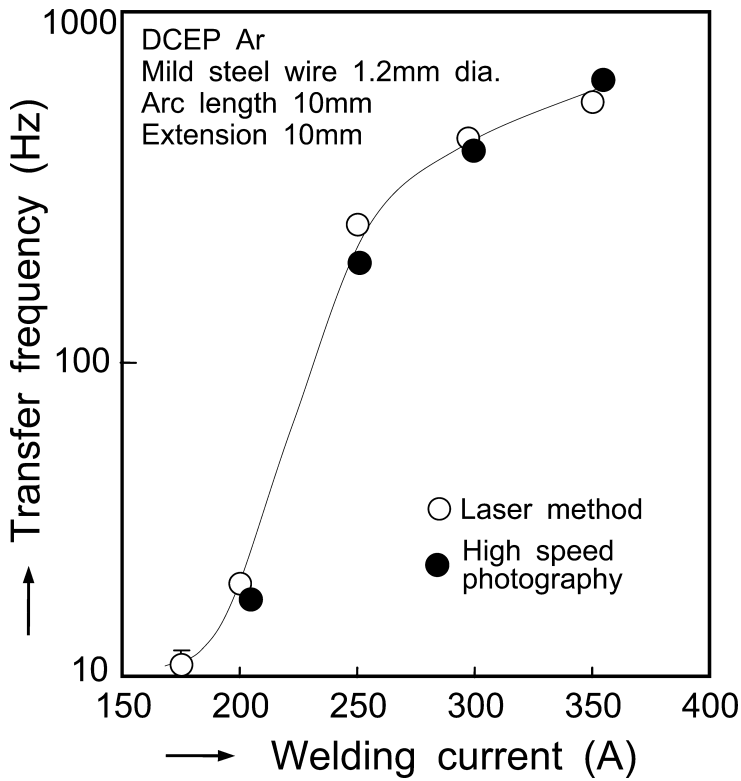

図 5 ミグ溶接における電流と溶滴移行回数の関係

図 4 ガスメタルアーク溶接における電流・電圧 条件と移行形態 

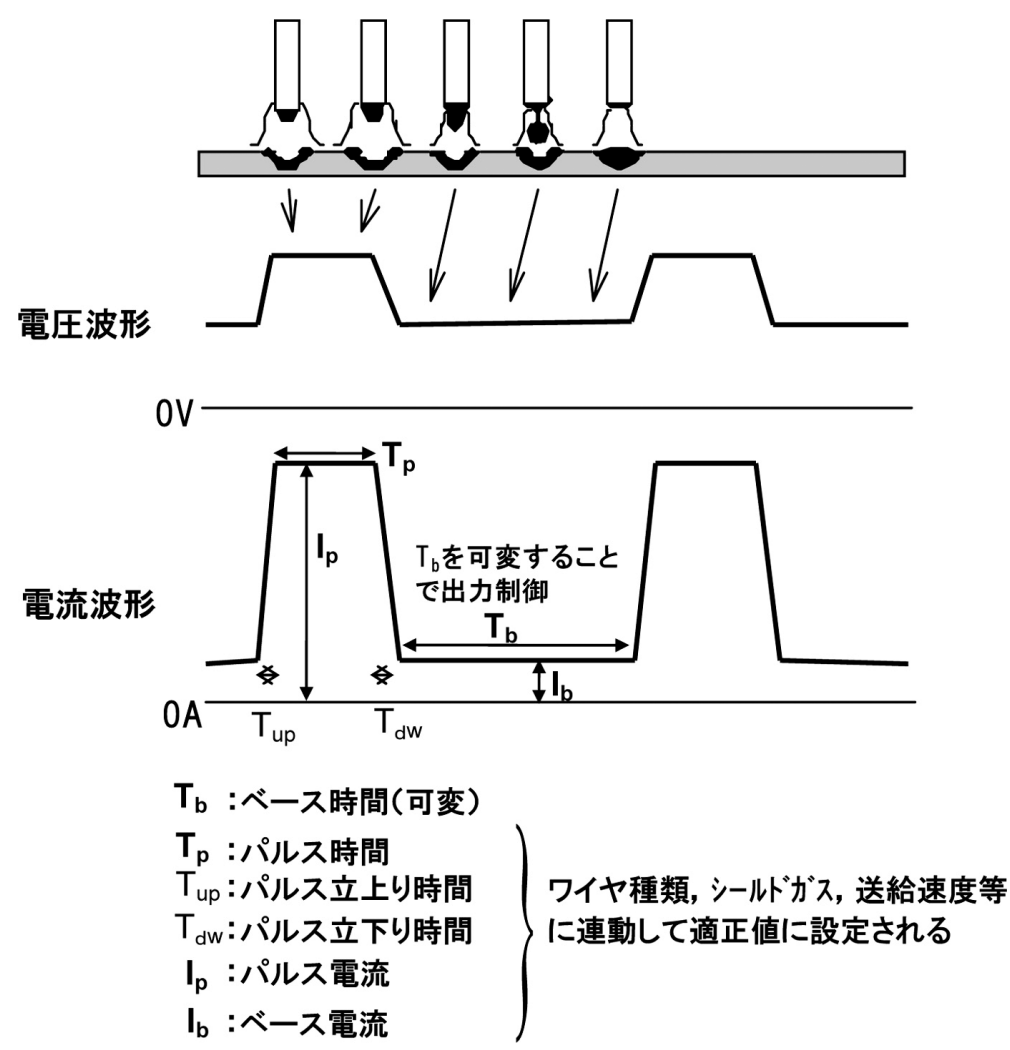

図 6 1 パルス 1 溶滴移行

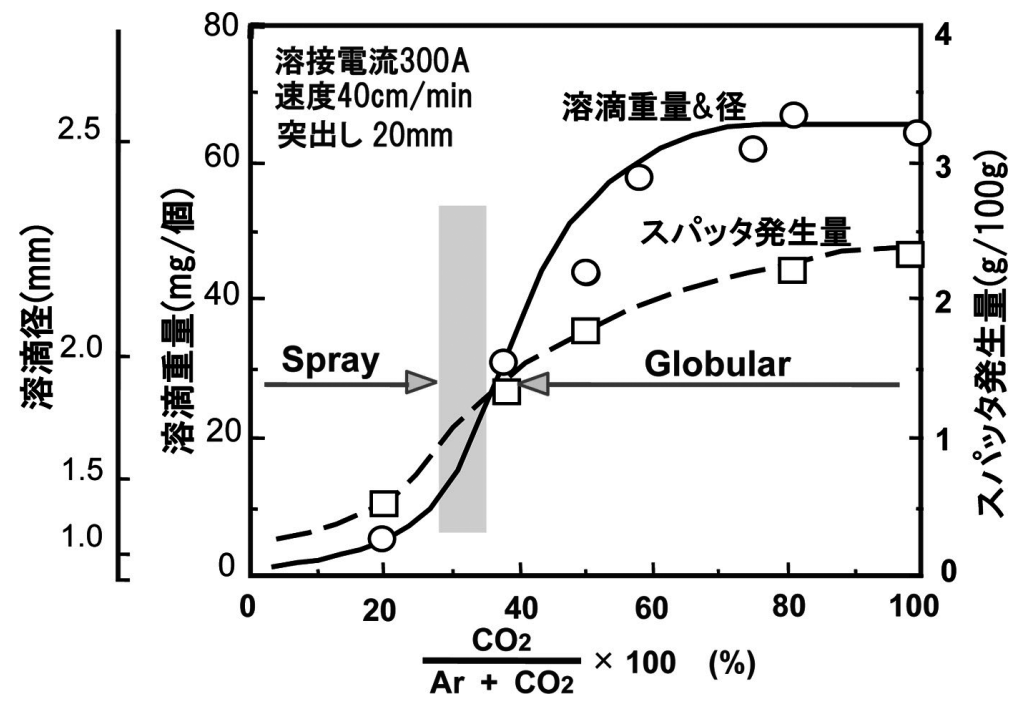

図 7 ガス組成と溶滴重量およびスパッ夕発生量の関係

はなく，後述するようなシミュレーションを併用しなが ら，基礎的な研究が進められている.

\section{4. 液滴と橋絡液柱}

液体の表面には表面張力が働いている．溶滴のよう に，表面をもつ液体の大きさがミリメートルオーダ以 下の場合，表面張力は液体の形状や流動に対して大き く影響する。

4.1 表面張力による圧力

まず，もっとも簡単な場合として，雨粒のような球状 の液滴に働く力を考えてみよう．液面が平面のときには,
表面張力は面内に引っ張り合う力として働き, 液体内の 圧力はそれに接触している雲囲気の圧力に等しい. しか し, 液面が曲面になると, 液面に働く表面張力と曲面の 形状・曲率によって, 液体内部の圧力と䨌囲気圧力との 間に差異が生じる。この表面張力による圧力は，次のラ プラスの式を用いて表わすことができる.

$$
\Delta P=\gamma\left(\frac{1}{R_{1}}+\frac{1}{R_{2}}\right)
$$

ここで, $\Delta P$ : 液体の内圧と䨌囲気圧との差 $[\mathrm{Pa}], \gamma$ : 液 体の表面張力 $[\mathrm{N} / \mathrm{m}], R_{1}, R_{2}$ : 液体表面の二つの主曲率半 径 $[\mathrm{m}]$ である. 例えば, 直径 $2 \mathrm{~mm}$ の水滴（水の表面張 


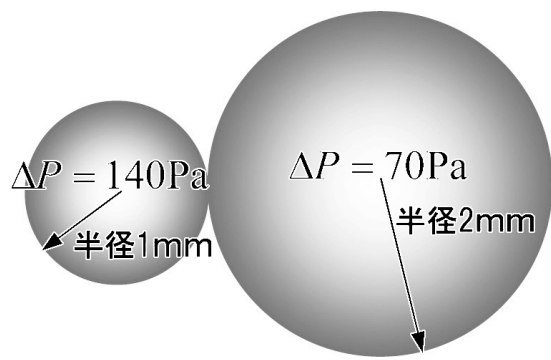

水滴 $\mathrm{A}$

図 8 表面張力による水滴の内圧

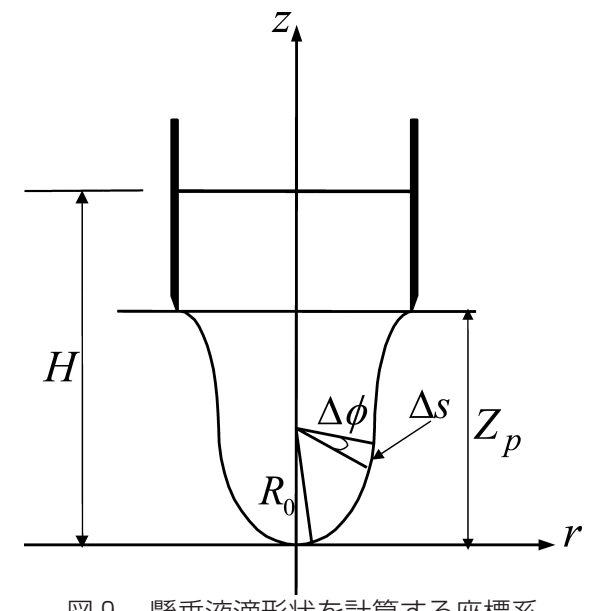

図 9 懸垂液滴形状を計算する座標系

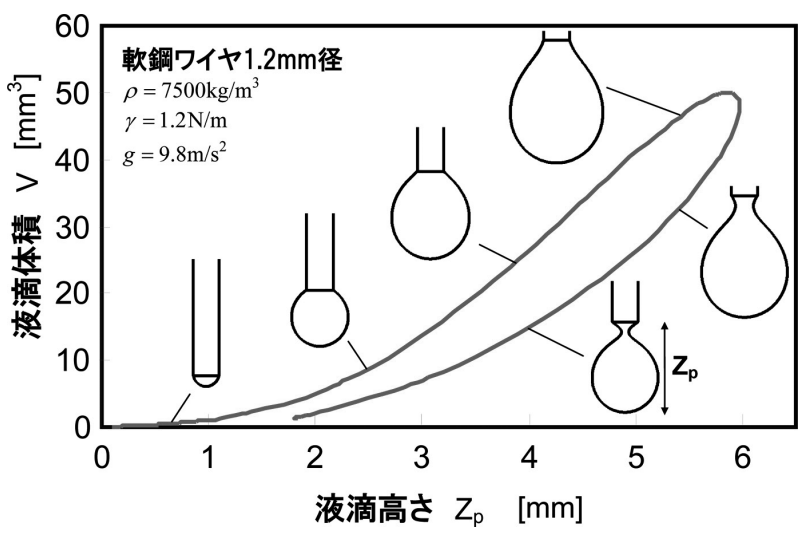

図 10 懸垂液滴の高さと体積の関係

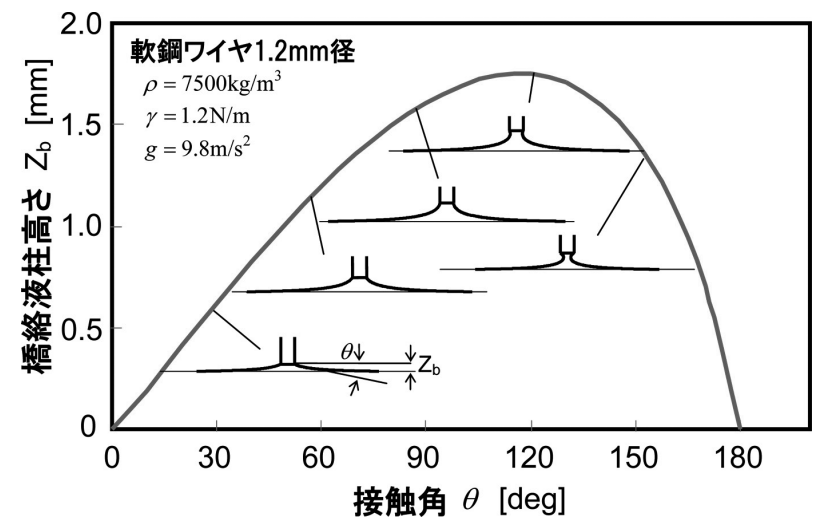

図 11 橋絡液柱の高さと接触角の関係

力 $0.07 \mathrm{~N} / \mathrm{m})$ の内圧は, 曲面が球体であるので $R_{1}=R_{2}=$ $0.001 \mathrm{~m}$ から, $\Delta P=140 \mathrm{~Pa}$ となり, 雲囲気圧（大気圧） より，140 Pa だけ高くなっている．いま，図 8 に示すよ うに，大きさの異なる水滴が接触したときを考えよう. サイズの大きい水滴 $\mathrm{B}$ の内圧は $70 \mathrm{~Pa}$ であり, 接触部に おいては, 小さいサイズの水滴 $\mathrm{A}$ のほうがその内圧が高 くなる. したがって, 内圧が高い水滴 $\mathrm{A}$ から水滴 $\mathrm{B}$ に向 かって，液体が流れ込むことになり，液滴は一体化する. そのほかの力が働いていない場合, 表面張力による内圧 が流れを駆動する力になる.

\section{2 懸垂液滴}

図 9 に示すようなガラス管中の液体が垂れ下がるよう な状態を考えよう．液滴底部では高さ $H[\mathrm{~m}]$ 分の重力に
よる静水圧 $\rho g H[\mathrm{~Pa}]$ が加わっており, これと表面張力に よる内圧 $\Delta P$ とつりあっている.したがって, 液滴の各 位置に対しては次式が成り立つ.

$$
\gamma\left(\frac{d \phi}{d s}+\frac{\sin \phi}{r}\right)=\rho g(H-z)
$$

ここで, $\rho g H=2 \gamma / R_{0}, R_{0}$ : 液滴底部の曲率半径 $[\mathrm{m}]$, $\rho$ : 液体密度 $\left[\mathrm{kg} / \mathrm{m}^{3}\right]$ である. 液滴底部の曲率半径 $R_{0}$ も しくは等価液柱高さ $H$ を変えて数值計算すると, 図 10 に 示すようにさまざまな液滴形状が得られる．図はその液 滴の体積と液滴高さとの関係を示しているが, 液滴の体 積 $V$ は液滴高さ $Z_{p}$ に対して, 最大值をとるまで単調増加 し（この範囲では液滴にはくびれがない），それよりも液 
滴を長くしょうとしても，体積は急激に減少する，そし て，くびれが大きくなり体積 $V$ は液滴高さ $Z_{p}$ とともに減 少する。したがって，ワイヤの溶融などのように時間と ともに溶滴の体積が増加する場合, 最大体積が安定限界 となり, 液滴長さの上限 $Z_{\text {pmax }}$ も規定されることになる. 言い換えると, 電磁力など他の力が働いていない場合, 液滴の質量（体積）が表面張力による保持限界を超える と棒端付近から離脱することを意味し，いわゆる自由移 行が起こる.

\section{3 橋絡液柱}

丸棒をプールに浸してから，静かに引き上げると棒端 と液面との間に橋絡液柱が形成される。 ラプラスの式か ら計算で求めた橋絡液柱の高さ $Z_{b}$ と丸棒端部での接触角 $\theta$ との関係を図11に示す，接触角の大きい領域では液柱 の形状にはくびれ部があり，振動などの外乱に対して不 安定である．また，ブリッジが形成される高さには，最 大值が存在することがわかる，つまり，これ以上の長さ の橋絡部を形成しょうとしても，橋絡部は破断すること を示している．この最大高さ $Z_{b \text { max }}$ は液体の種類（表面張 力, 密度) や棒径によって異なる.

\section{5. 溶滴移行における電磁力の役割}

電極ワイヤ端の溶融金属には，表面張力と重力に加え て電磁力やプラズマ気流による摩擦力などが複雑に作用 している.とくにワイヤ端には電流が集中しているので, 移行現象に抢よぼす電磁力の影響が大きい.

まず，電流が溶滴やアークの内部を流れることによっ て，どのような力が発生するのかについて考えてみよう. 図12に示すように平行においた 2 本の金属線内を電流が 流れるとき，それぞれの金属線に流れる電流により磁界 が発生し, その磁界と電流との間に電磁力が働く。電磁 力の方向は, フレミングの左手の法則に従い, 電流の向 きが同じ場合，互いに吸引力として働く、いま, アーク や溶融金属などの導電性の流体に電流が流れるとき，流 体の断面形状が円形ならば，その力は図13 (a)のように 中心部に向かう。このため, 流体中心部では外周部より 圧力が高くなる (電磁誘導圧力). 電磁圧力 $P_{e m}[\mathrm{~Pa}]$ は電 流 $I[\mathrm{~A}]$ と電流密度 $J\left[\mathrm{~A} / \mathrm{m}^{2}\right]$ の積に比例し, 次式で与えら れる。

$$
P_{e m}=\frac{\mu_{0}}{4 \pi} J \cdot I
$$

ここで, 半径 $R[\mathrm{~m}]$ の円柱状の導電性液体に働く圧力を 考える. 液体であるので, 液柱内部には (1) 式で表現さ れる表面張力による圧力が働いている. さらに電流 $I[\mathrm{~A}]$ が流れると (3) 式による電磁圧力が加わるので, 液柱の 中心圧力 $P[\mathrm{~Pa}]$ は次式のようになる.

$$
P=P_{0}+\frac{\gamma}{R}+\frac{\mu_{0} I^{2}}{4 \pi^{2} R^{2}}
$$

ここで, $P_{0}$ : 雲囲気圧力 $[\mathrm{Pa}]$ である. 図13 (b) のように 液柱にくびれが生じると電流通路が狭くなるため, 定性 的には (4) 式から圧力が高くなることが理解できる。い

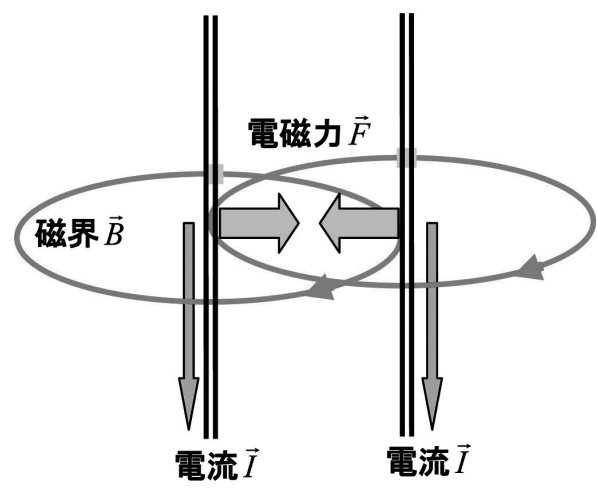

図12 電磁力の発生

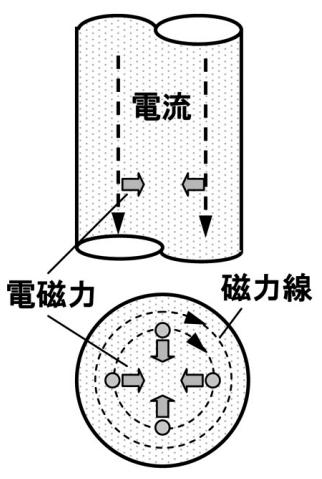

(a)

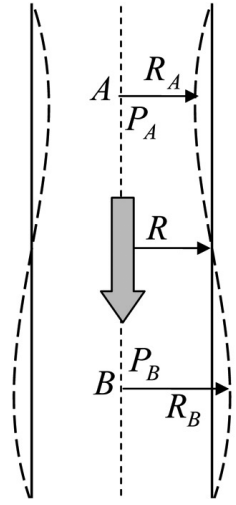

(b)
図 13 導電性液体円柱に働く電磁圧力

ま，液柱表面がわずかに変位し，破線で示すようにくび れ部 (半径 $R_{A}$ ) と膨れ部 (半径 $R_{B}$ ) が形成された場合を 考える. (4) 式から $R_{A}<R_{B}$ のとき，〈びれ部 $\mathrm{A}$ 点の圧力 $P_{A}$ は膨れ部 $\mathrm{B}$ 点の圧力 $P_{B}$ よりも高くなる. したがって, 軸方向に圧力勾配が生じるので，くびれ部から膨れ部に 向かう流れを駆動することになり，〈びれ部の液体はま すます膨れ部に移動し, 結果として液柱を分離, 破断す ることになる. ワイヤ端の溶滴が球状の場合，このよう な機構によって溶滴が離脱すると考えてもよい.

\section{6. シミュレーションによる移行プロセス の理解}

ここ数年の間に, コンピュータの性能が格段に向上し, 複雑な溶接現象をモデル化し, シミュレーションできる 環境が整ってきた。ここでは筆者らにより開発した計算 モデルを通して得られた知見について, 簡単に述べるこ とにする。

\section{1 短絡移行}

ガスメタルアーク溶接の短絡移行においては, ワイヤ 端と溶融池との間に橋絡部が形成されるので, 上述した 表面張力による圧力に加えて, 短絡電流による電磁ピン チ力が作用する. 解析対象としては, 最近のインバータ 電源による電流波形制御溶接を想定し，図14に示すよう な移行状況をモデル化している。つまり，(1)アーク電流 でワイヤ溶融量を制御して, 特定の大きさの溶滴をワイ 

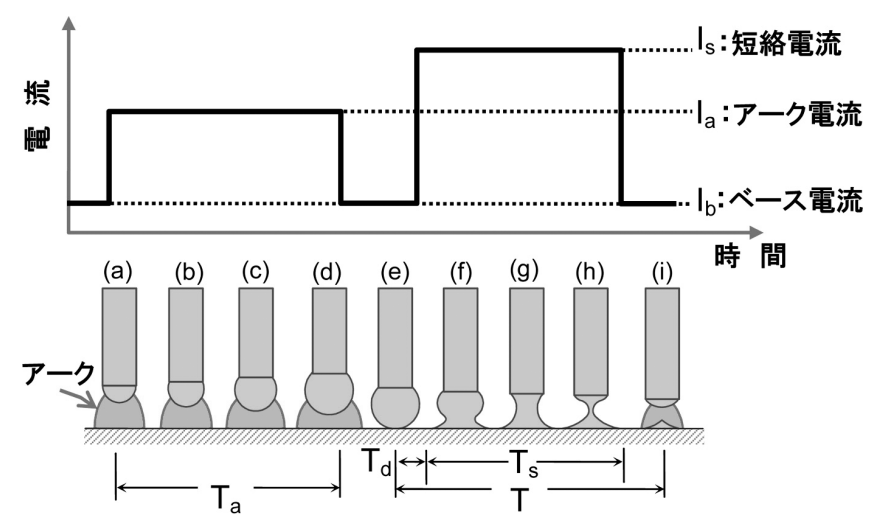

図 14 短絡移行プロセスの電流波形制御

(a) $I_{\mathrm{s}}=0$

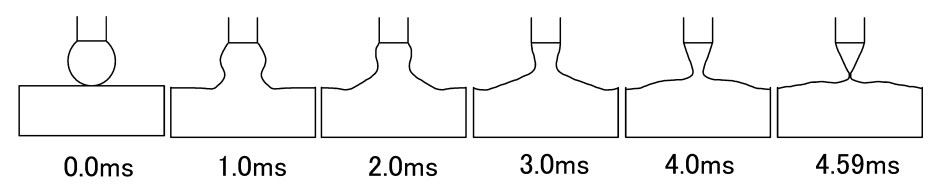

(b) $I_{S}=400 A$

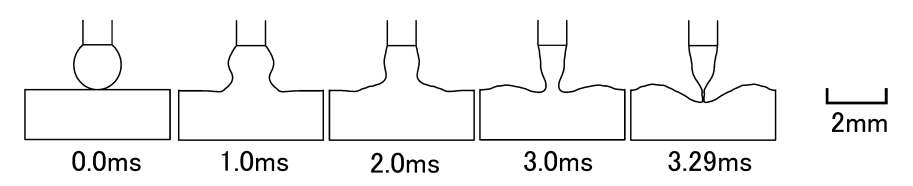

図 15 短絡移行現象のシミュレーション（軟鋼ワイヤ $1.2 \mathrm{~mm}$ 径）

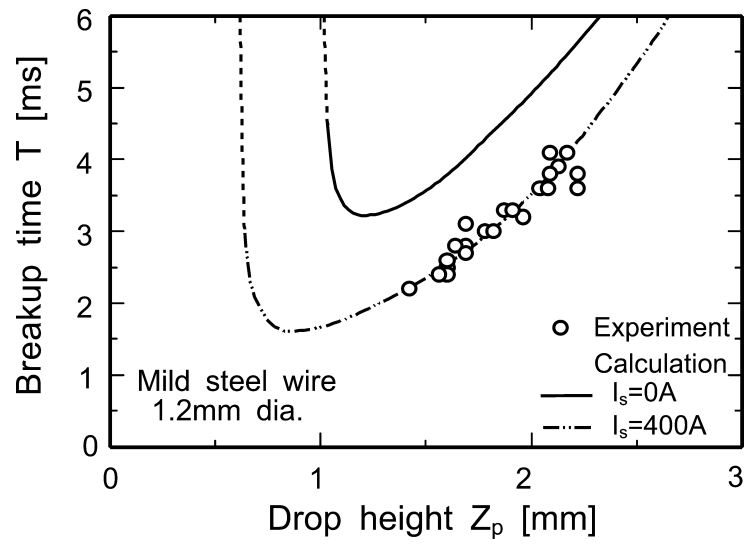

図 16 溶滴高さと破断時間の関係

ヤ端に形成し，(2)電流值を低くした後，溶滴とプールと を静かに接触させて，毛管現象を利用してある程度移行 させたのち（接触してから $T_{d}$ 時間の時間おくれを持たせ て), (3)短絡電流 $I_{S}$ を $T_{S}$ 時間通電し, 電磁ピンチ力で橋 絡部を強制的に絞り，橋絡した状態で一旦電流值を下げ, (4)ブリッジの破断は慣性力を利用して，低電流で再点弧 させる.このような波形制御は再点弧時などのスパッ夕 発生を抑制することを目的としている. ワイヤ径 $1.2 \mathrm{~mm}$ の軟鋼溶滴が溶融池に接触してから，橋絡を形成した後， 破断するまでの溶滴の挙動を図15に示す。ここでは，溶 滴が溶融池に接触してから $1 \mathrm{~ms}$ 後に $400 \mathrm{~A}$ の短絡電流を 通電している。図16は溶滴サイズと破断時間の関係を示 したものである。接触前のワイヤ端の溶滴サイズが大き いほど，橋絡部を破断する時間が長くなっており，実験

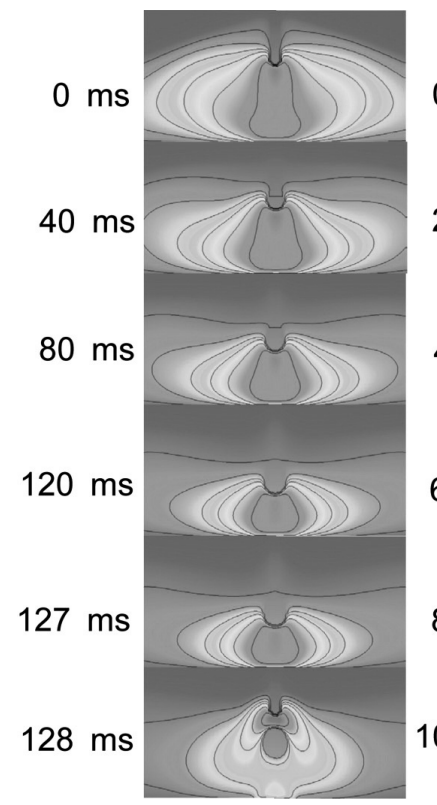

(a) $100 \mathrm{~A}$

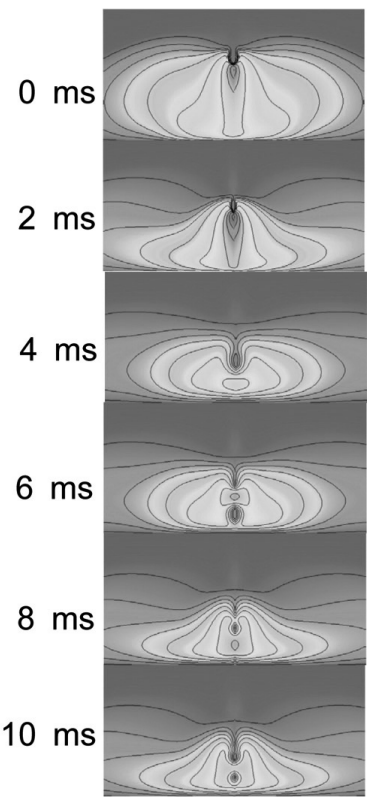

(b) $250 \mathrm{~A}$
図 17 ミグ溶接の自由移行のシミュレーション （軟鋼ワイヤ $1.2 \mathrm{~mm}$ 径）

結果とよく一致している ${ }^{14,15)}$.

\section{2 自由移行}

図17はミグ溶接の自由移行プロセスを数值シミュレー ションした結果である ${ }^{16,17)}$. 電流值が低い場合，電磁力は 表面張力や重力に比べるとかなり小さく, ワイヤ端の溶 滴は図10に示すような形状をとりながら大きくなる.そ して，溶滴はワイヤ径よりも大きくなって，離脱する， 
いわゆるグロビュラー移行となる，このとき，溶滴移行 に伴ってアークプラズマの形状や大きさが変化すること が分かる．一方，電流值を高くすると，ワイヤ溶融速度 が大きくなるので，蛇口から水が流出するように，溶融 金属はワイヤ端から流れる．同時に，強い電磁ピンチ力 の作用により溶融金属は細く絞られながら，軸方向に引 き伸ばされるようにして，小さな溶滴が離脱するスプレ 一移行形態となる. また, 溶滴移行に伴うアークプラズ マの変動も小さいことが分かる.

このワイヤ端の溶融金属の形状や離脱する溶滴の大き さは，液体金属の流動性だけに注目すると，溶融金属の 粘性や表面張力が大きく支配するが，より深く考えると， ワイヤはアークによって溶かされ, 離脱力となる電磁力 は電流経路が支配するので，プラズマガスの熱伝導率や 導電率などが大きく影響することになり， シールドガス の種類によってワイヤ溶滴や移行状態を変えることがで きる.このように，溶滴移行に伴うガスメタルアークの 形状変化，すなわち，母材にとっての熱源の大きさや入 熱量，アーク圧力なども予測できるようになりつつある.

\section{7. おわりに}

ミグ/マグ溶接は，プロセスの構成要素であるワイヤ・ シールドガス・電源について，それぞれの性能を向上さ せるとともに，その組み合わせのありかたを追求するこ とで，さらなる進化をする可能性がある。 そのポイント はアークの安定性と溶接品質, 作業性を支配する溶滴移 行をいかに制御するかということであり，そのためには ワイヤ溶融・溶滴移行現象の本質を見極める必要がある. 現在, 統合モデルと呼ばれている「溶滴移行ーアーク放 電一溶融池」を包括的に理解するモデルの開発が国内外 で進められており，今後，その知見に基づいた新しいプ ロセスが開発されるものと期待している.

本稿では溶滴移行現象に焦点を絞って解説してきたが, 溶接プロセスという観点からのミグ溶接・マグ溶接の特 徵については紙数の関係で割愛している。これらについ ては，溶接学会が刊行しているテキストや本稿の引用文 献などを参考にしていただければ幸いである。

\section{参考文献}

1）溶接学会編：溶接・接合技術特論, 第 1 章, 産報出版 (2003).

2）溶接学会編：溶接 - 接合技術概論，第 1 章，産報出版 (2002).

3）中野，松田：アーク溶接のスパッタレスと高品質溶接への 取り組み，溶接技術 Vol.53 (2005) No.8.

4) 三田：わが社のイナートガスアーク溶接機の現状と将来展 望，軽金属溶接 Vol.43 (2005) No.4.

5) 濱本, 川本，米森，印南：デジタルアーク溶接機の開発, 溶接法ガイドブック 5 「溶接プロセスの高効率化」(2004) II-99，溶接学会溶接法研究委員会編.

6) 全, 上山, 原田：最近のデジタル制御イナートガスアーク 溶接機の進展，軽金属溶接 Vol.43 (2005) No.4.

7）古川：欧州におけるイナートガスアーク溶接機，軽金属溶 接 Vol.43 (2005) No.4.

8) G. Huismann: Introduction of a new MIG process Advantage and possibility, IIW Doc.212-952-99 (1999).

9) K. Himmelbauer: The CMT-Process - A revolution in welding technology, IIW Doc. XII-1875-05 (2005).

10) Classification of metal transfer on arc electric welding processes, IIW Doc. XII-636-76, 1976.

11) 丸尾, 平田, 野田 : パルス MIG 溶接における溶滴移行と ビード形成におよぼす電流波形の効果，溶接学会論文集， Vol.2 (1984) No.1.

12) 山本：レビュー\&トレンド「アーク溶接電源」, 溶接学会 誌 Vol.66 (1997) No.8.

13) 片岡, 池田, 安田ほか：溶接法研究委員会資料, SW2893-03 (2003)

14）平田, 長村, 恩田, 安藤, 黄地：短絡移行プロセスのモデ ル化，溶接学会論文集 Vol.22 (2004) No.2.

15) Y. Hirata, N. Ando, T. Osamura, M. Onda and T. Ohji: 3D Numerical Model of Short-Circuiting Transfer Process in GMA Welding, Mathematical Modelling of Weld Phenomena Vol.7 (2005).

16) Y. Hirata, T. Ohji, and M. Ushio : Material Transfer in Gas Shielded Metal Arc Welding, Proc., $7^{\text {th }}$ International Aachen Welding Conference, Vol.1 (2001) 253-268.

17) Y. Hirata, K. Ohnishi, K. Hiraiwa and T. Ohji: Numerical Model of Arc plasma with Metal Transfer in Argon Gas Shielded Metal Arc Welding, IIW Doc. 212-1076-05 (2005). 